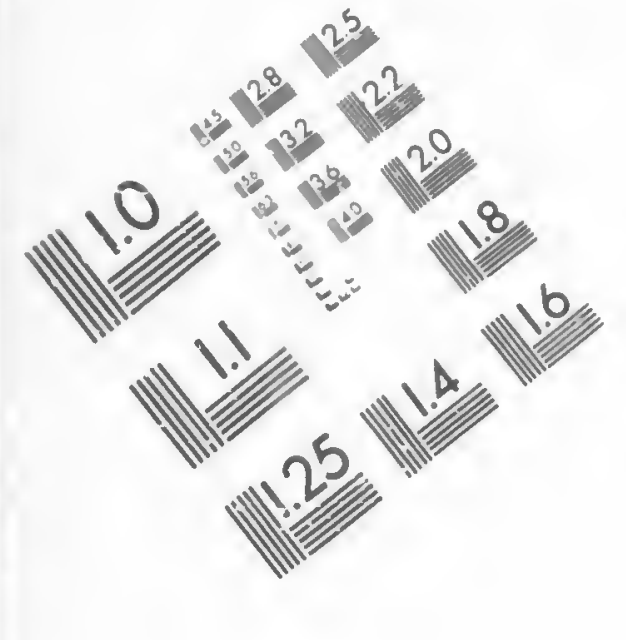

IMAGE EVALUATION
TEST TARGET (MT-3)
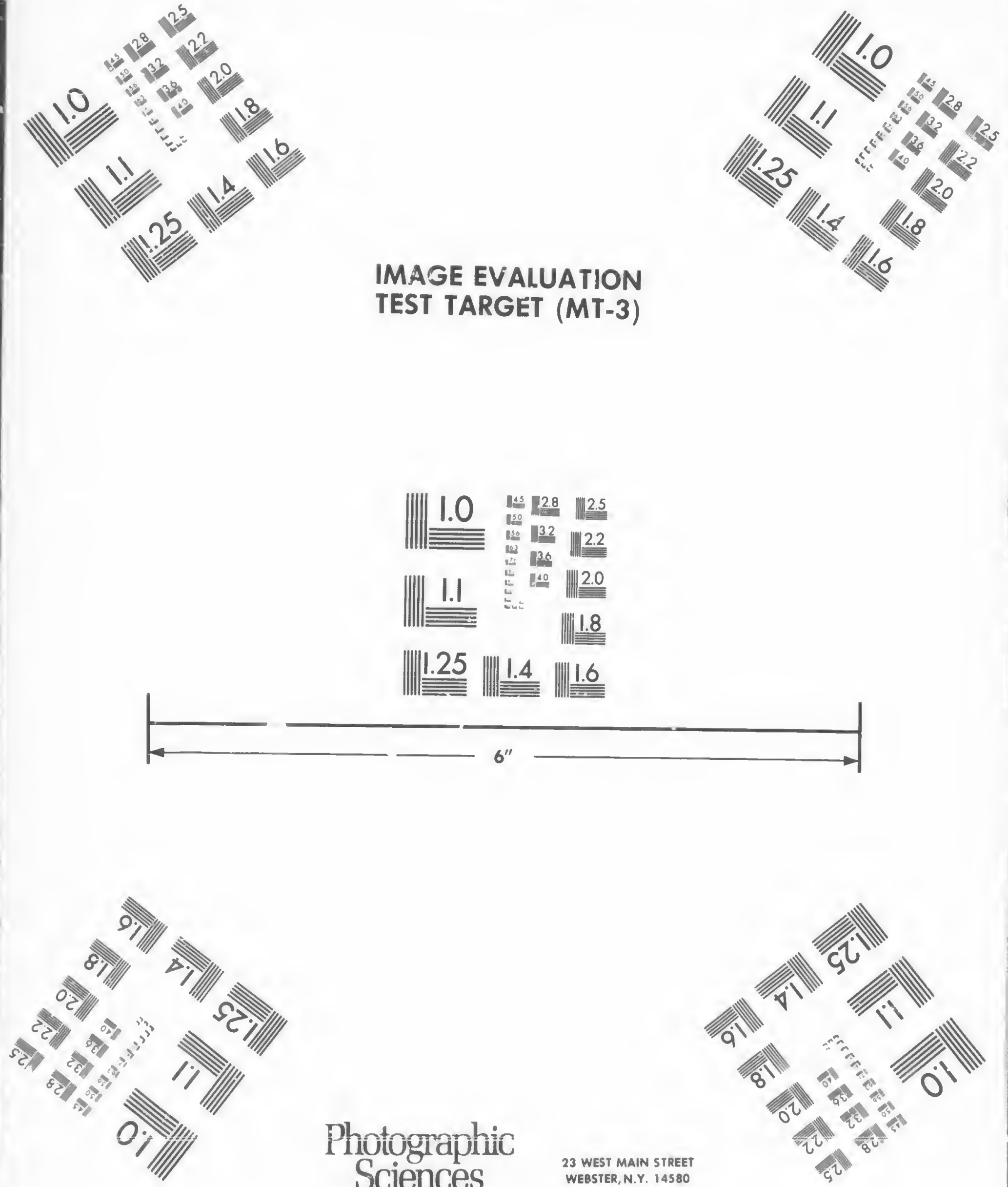

Photographic Sciences Corporation

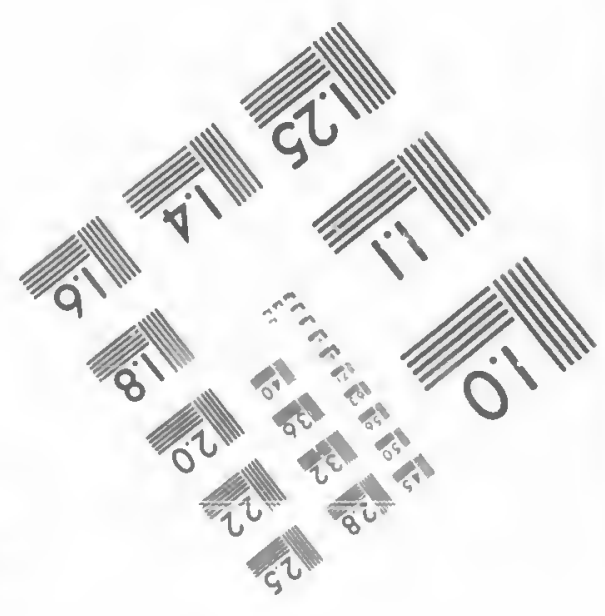


CIHM/ICMH Microfiche Series.

\section{CIHM/ICMH Collection de microfiches.}

Canadian Institute for Historical Microreproductions / Institut canadien de microreproductions historiques
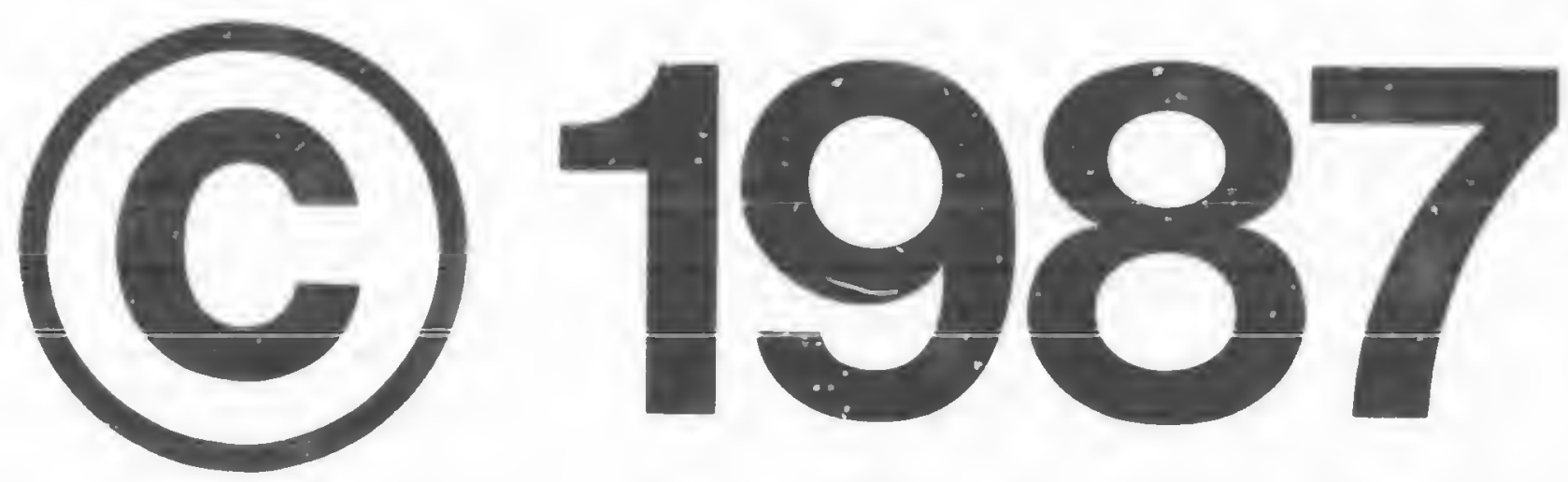


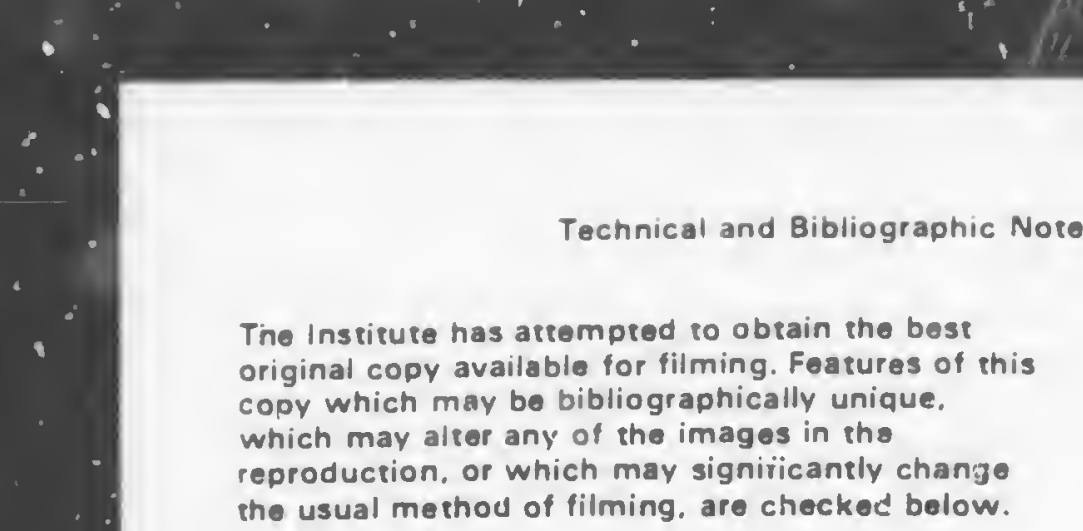

Coloured covers/

Couverture de couleur

Covers damaged/

Couverture endommagée

Covers restored and/or laminated/

Couverture restaurbe et/ou pelliculé

Curst title missing/

Le vitre de couverture manque

Coloured maps/

Cartes géographiques en couleur

Coloured ink (i.e. other than blue or black)/

Encre de couleur (i.e. autre que bleue ou noirel

Coloured plates and/or illustrations/

Planches et/ou illustrations en couleur

Bound with other material/

Relib avec d'autres documents

Tight binding may cause shadows or distortion along interior margin/

La reliure serrée peut causer de l'ombre ou de la distorsion le long de la marge intérieure

Blank leaves added during restoration may

appear within the text. Whenever possible. these have been omitted from filming/

II se peut que certaines pages blanches ajoutdes lors d'une restauration apparaissent oans le texte. mais. lorsque cela stait possible, ces pages n'ont pas éto filmdes.

Additional comments:/

Commentaires supplémentaires.
L'Institut a microfilmé lo meilleur exemplaire qu'il lui a dte possible de se procurer. Les details de cet exemplaire qui sont peut-ère uniques du point de vue bibliographique, qui peuvent modifier une image reprociuite, ou qui peuvent exiger une modification dans la móthode normale de filmage sont indiqués ci-dessous.

Coloured pages/

Pages de couleur

Pages damaged/

Pages endommagées

Pages restored and/or lamirated/

Pages restaurbes ot/ou pelliculées

Pages discoloured, stained or foxed/

Pages dhcc!orées, tachetées ou piquèes

Pazes detached/

Pages détachees

Showthrough/

Transparence

Quality of print varies/

Qualité inégale de l'impression

Includes supplementary material/

Comprend du masériel supplémentaire

Only edition available/

Soule edition disponible

Pages wholly or partially obscured by errata slips, tissues. etc.. have been refilmed to ensure the best possible image/ Les pages totalement ou partiellement obscurcies par un feuillet d'errata. une pelure. etc. cnt tí film.ées à nouveau de facon à obtenir la meilloure image possible.

This item is filmed at the reduction ratio che -ked below/

Ce document est filmé au taux de réduction indiqué ci-dessous.

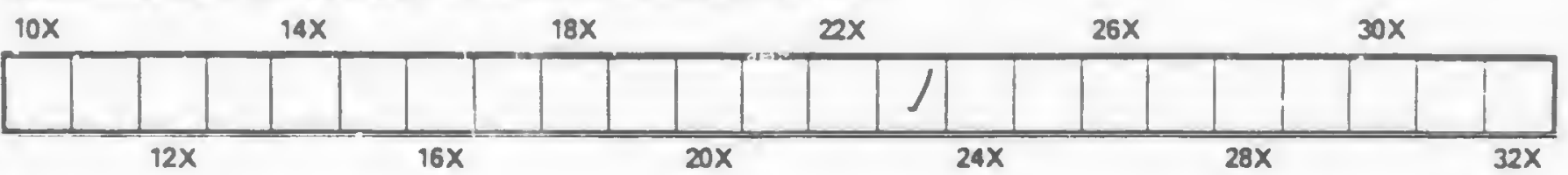


The copy filmed here has been reproduced thanks to the generoslty of:

Harold Campbel! Vaughan Mamorial Library Acadia University

The images appearing here are the best quality possible considerlng the conditlon and legibillty of the original copy and In keeplng with the filming contract specificatlons.

Original copies in printed paper covers are filmed beginning with the front cover and ending on the last page with a printed or illustrated Impression, or the back cover when appropriate. All other original coples are filmed beginning on the first page with a printed or illustrated impression, and ending on the last page with a printed or illustrated impression.

The last reccrded frame on sach microfiche shall contain the symbol $\rightarrow$ Imeaning "CONTINUED"), or the symbol $\nabla$ (meaning "END"), whichever applies.

Maps, plates, charts, etc., msy be filmed at different reduction ratios. Those too large to be entirely included in one exposure are filmed beginning in the upper left hand corner, left to right and top to bottom, as many frames as required. The following diagrams lllust: ate the method:
L'exemplalre fllmé fut reprodult grâce à la gónórosito de:

Harold Campbell Vaughan Memorial Library Acadia University

Les Images suivantes ont 6t6 reprodultes avec le plus grand soin, compte tenu de la condltion et de la netteté de l'exemplalre film6, et en conformité avec les conditlons du contrat de filmage.

Les exemplaires orlglnaux dont la couverture en papler est imprimbe sont filmós en commençant par le premler plat et en torminant soit par la dernière page qui comporte une empreinte d'impression ou d'illustration, solt par le second plat, selon le cas. Tous les autres exemplaires origlnaux sont filmbs en commençant par la premlère page qui comporte une empreinte d'impression ou d'illustratlon et en termlnant par la dernière page qul comporte une telle empreinte.

Un des symboles suivants apparaîtra sur la derniere Image da chaque microfiche, selon le cas: le symbolt $\rightarrow$ signifie "A SUIVRE", le symbole $\nabla$ signifie "FIN".

Les cartes, planches, tableaux, etc., peuvent etre film6s à des taux de réduction differents.

Lorsque le document est trop grand pour etre reproduit on un seul clich6, il est film6 à partir de l'angle supérieur gauche, de gauche à droite, et de haut en bas, on prenant le nornbre d'images nócessaire. Les diagrammes suivants illustrent la móthode.
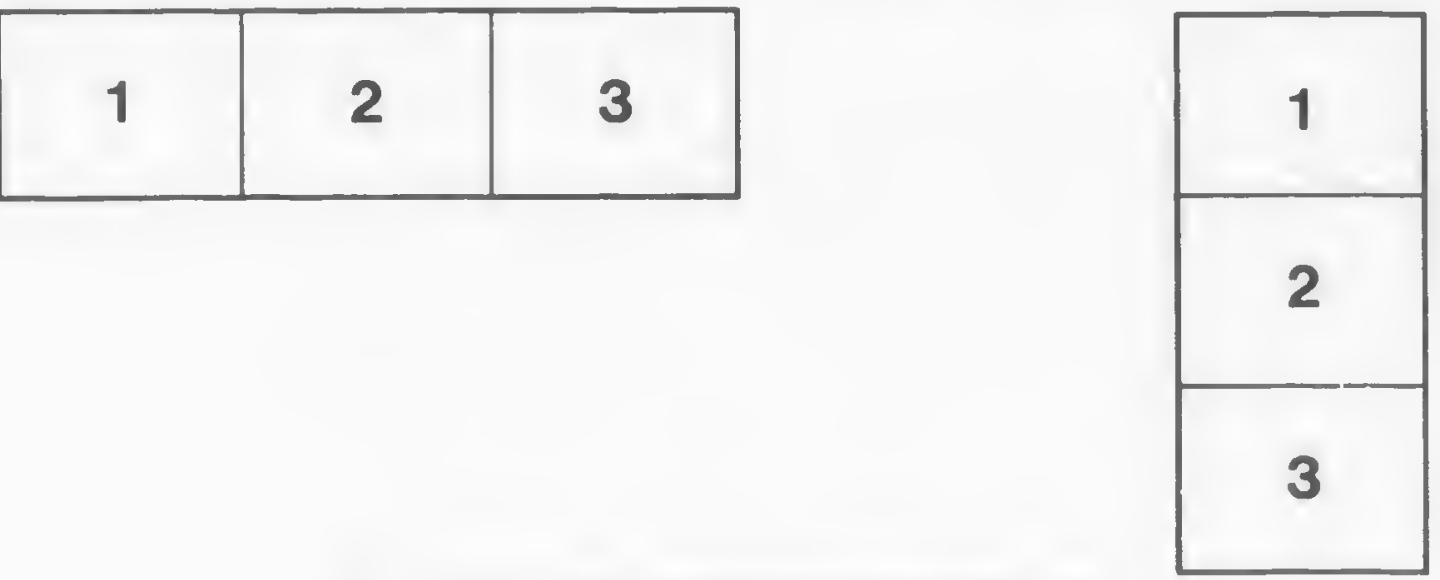

\begin{tabular}{|l|l|l|}
\hline 1 & 2 & 3 \\
\hline 4 & 5 & 6 \\
\hline
\end{tabular}


FROM THE TRANSACTIONS OF THE ROYAL SOCIETY OF CAYADA SECOND SERIES-1897-98

VÓLUME III

SECTION IV

GEOLOGICAL AND BIOLOGICAL SCIENCES

\title{
JOHN GOLDIE, BOTANIST
}

\author{
By G. U. HAY, Ph.B., M.A.
}

FOP, YALE BY

J. DURIE \& SON, OTTAWA; THE COPP-CLARK CO., TORONTO BERNARD QUARITCH, LONDON, ENGLAND

1897

A

9ุ 20

$g^{56} \mathrm{~h}$ 


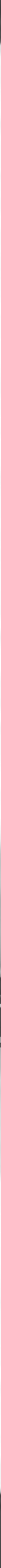




\section{V.-.John Goldie, Bolanist.}

By ('., U. HAy, I'H.B., M.A.

(Reul June gurd, 1897.)

It is not inappropriate, in connection witl the Cabot celebration. to introduce the name of Joh. Goldic, bntanist, who, 80 years ago, in June, 1817, ut the instance of Sir Wm. Hooker, left Ieitl: and shortly at te; landed in Ialifax te make investigations of the flora of C'matda und the United States. His researches were rewarded by the discorery of many new plants, but most of these unfortunately were lost in transportution to (ireat Britain; and his lotes, contuining sketches and descriptions of his discoveries, were destroyed by tire at a later date. Sufficient, however, has been handed down to show his great industry in botanieal research, and the importance of his discoveries. He had many of the characteristies, too, of the discoverer. Of a haldy constitution, fearless clisposition, patient in his investigations, accurate in his judgments, and ivith a findness for his favourite seience that no fat igue or discou ragements could overcome, he is not unworthy of a place among those brave spirits of the old world who became the pioneers of' researeh in Canada.

It is to be regretted that the botanical journal in which Mr. (toldie kept a record and descriptions of the plants diterevered, wis destroyed. A diary of a journey through Upper Canada and some of the Northern States in 1819 has been preserved, and was published this year (1897) in Toronto. A list of the new and late plants found by Mr. Goldie during his two years' explorations in A mericu was published in the Edinburgh Philosophical Journal for A pril, 18:2. This contains a brief account of his jun "ney with descriptions of new plants. To both of these the writer hals had acess, and with alditional information kindly furnished by IIr. James Goldie, of Guelph, Oritario, son of the botanist, anl himselt a botanist und horticulturist, he has obtained materials for this sketch. which, meagre in regard to scientitic information of his researches, may be found to possess some interest to botanical and general siudents, interwoven as it is, to some extent, with the purpose that bi ings the suriety together at this time and place.

During his lifetime Mr. Goldie canried on an extensive correspondence, particularly after he came to Canada to reside, with many prominent botanists of the old world. and especially with his friend, Sir $W_{m}$. Iooker. But no perinanent record of the results of this correspundence has been preserved. except such as has found it: way into the published writings of these botunists, to which, however, no access has been possible in the preparation of this memoir.

sec. 11.. 1\$\%. 7. 

nentions several interesting plants, among thenn ngellow flowered variety of' Sarrerenia plirpurea, whish he never noticed elwewhere. From flalitix he procended to the north shore ol New Brumwick, where he suent some time. He often me.tioned the benutiful orchid-Calypsoborealis-found near the Baic de Chaleurs. He made numerons sketehes of the count scenery, with notes on the geoingy und botany of the various places visitei. From Sew Brunnwick ho proceeled to Quebec, carrying with him all the ro.s:s and specimens that he had obtained. which, with the

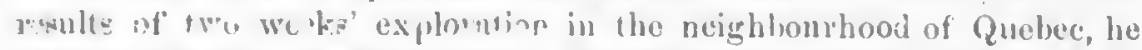
placel co bourl a ressel bonnd for Greenock, but never heard of them afterwals.s. The same fate awaited two collections afterwarls made, the sno shipped from Now York, the other from Ilontreal.

Fom Quebce Mr. (iohlie proceded to Montreal, where he met Fred"vick Push. " "thor of" the North American lohn, who gave him much irformation which grublet hion in his future morements. Mr. Purnl

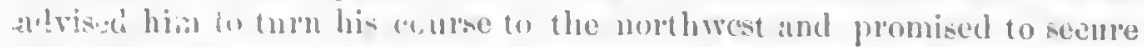

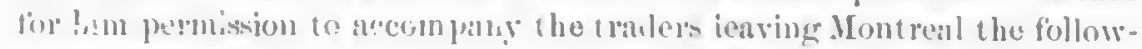
juL spring.

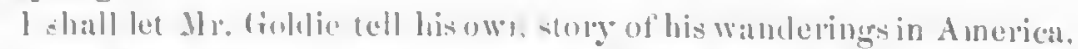

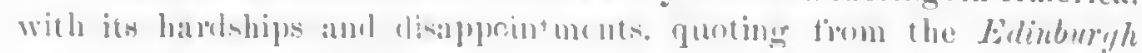

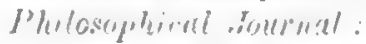

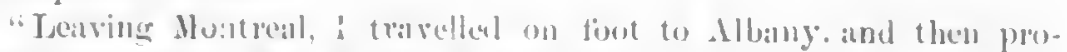
creded by water to Now York. I remanded but a vhort time in this last

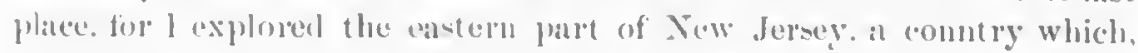
though batren and thinly inhabited. yet plesents matuy rapities to the

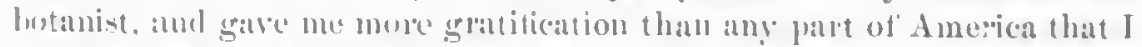

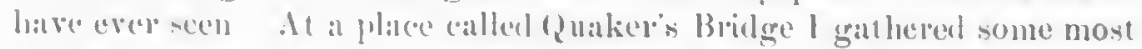
interenting plants, and loaving accumulated as lange a loal as my back monlal carry, I took my jonrney to Philadelphia, where l stail but a very short time, for, knowing that a ship was alwut to salil from Sew Fork to Scothnd. I hastened to return thither": and haring again entrusted my treasures to the deep, I hat again, as the filst time, the disappoint. ment of never obtaining any intelligence whatevere of them.

"Mg tinances being now extremely low, and wintel having eommenced, I hardly knew 1 hat to do: but aftel some delay went up the Molsawli river, where I foumd employment diang that season as a schoolmaster. I dputted this place in April. 1818, and proceded to Ifontran, expecting to he ready to mepart on my jonrneg twwals the uorthwest country. 1 was disappointed in fincling that iv r. Push had left M[notreal fii) Quebec, and that even if present. his interest would scurce have leen antheisntly strong to bave oblatuch far ne the assistance and protection which I desirei. Ify only alcumative was mow the spade, at which l worked all summer. excepting anly two days in eateh week. which 1 de-

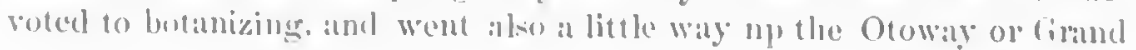


river, the only excursion of any length which I acemplishel. In the antumn I shipined ny collection of plants, and in two months had the mortification to learn that the ressel wiss totally wreeked in tho St. Law. l'ence. Thus did 1 loge the firuit of two years' labour. During the next winter I dich little, except employing inyself with sncl small skill as I was atele in designing some thower pieces, for which I got a trifle. Lilly in the following spring 1 eommenced Inbont again: anel by the begiming of June hat nuassed ahout tifty dollars, which, with us much more that ! bolrowed from a friend, folmed iny stock of money fiol the next wummer's (1nul. I started in the beginning of June from Ifontreal, and passing through Kingston went to Now York, to which, attele an exculsion to Iarke Simene, I returned; then visited the Falls of Niagara mul Fort firie, and crossed orer to the Cuited States, keeping along the eastern side of Lake lipie for ninety miles. I afterwarls took a direct enurse tor l'ittsburgh on the Ohio, which, owing to the alvanced state of the season, was the most distant point to which I conld attain. On my retun I kept along the sicle of the Alleghung river to Point Ollean, in the stinte of New York; then visited the salt works of Onondagro and Sackett's Hatbour on Lake Ontario, whenee, proceeding to Kingston, I packed up, my whole collection, with which I returned to Montreal, and emba"king on a ressel-which was bound to Greenock, got safely home; the plants which I earried with inyself being the whole that I saved out of the prodnce of nearly three years spent in botanical reseatreless.

"In spite of the ill-fortune which has hitherto attended my endear. omrs, I have still so great a desire to bring plants and seeds to this country that I purpose, in the ensuing spring, if my peeuniary circum. stanees will perinit me, to make another excursion to that conntry for the purpose of exploring the forests which lie towarl the west."

Mr. Goldie was not able to carry out his intentions.

In $182+$ he was rmployed by the hossian govermment to aseist in the formation of the new Botanic Gialden.s at St Petersburg, after which he Ghtained pasiports to visit difterent parts of Russia and wats thus enabled to examine its plants. When he returned to scotland he took with him a number of plants not hefore introduced into that comntry, among them Abies Sibericu, Peronin tenuifolia, and many others.

About the year 18,30 Ifr. (ioldie aganin visited Rinsia, and the government, in recognition of lis skill. asked him to investigate and report ujun the flora of some ot its recently acquired territory, but owing to businds. engagements at home he was compelled to dechine the congenial task.

In the couse of his wanderings through Canala, Mlr. (ioldie had formed a farourable opinion of the country, and came with his fomily. in 1844. to $\mathrm{Ay}$ r, Ontario, where he settled and eontinued to reside nutil hi. death. 
'l'wo of the new phunts deseribed by Mr. (ioldie are not found in our inanuals. and I have heen unabla to trace them owing to the want of aceess to al Iotunienl library. These ure Lithospermum linearifolimn anut Primula pusillu. The P'rimula, us figured in the pllate in the Philosophical oournal of $18 \% 2$, is a beautiful little plant not exceseling two or thros inches in height. Quotiug from :!r. Foldie's descrijution: "From l". mistussinica it differs by its rery unch smaller dimensions, whorter eap. sules, and partieularly its flowers, of which the caly:x is ollong und ulmost "qual to the tube of the corollat in length. 'The divisions of the corolla are considerably troader und more olbtuse-more resumlling those of $P$. farinosa, or even P. Srotica, from which two species again the form of its lenves keeps the $P$. pusilla distinct. The flowers are from foul to eight in number:"

What has become of this plant? Was roldie mintaken in its iden. tity :

l'uprifolium pubescens, now Lonivera hirsuth, and .lylostenm oblondi-

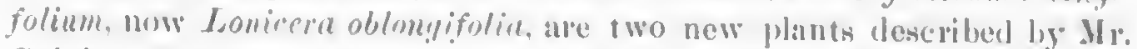
Goldie. The latter plant, known as the Swamp honeysuckle, was found un Joutreal island, and has not since heen found east of that place mutil last summer, when the writer discoveres it in the morthern part of New Brunswick.

In hiv description of Viola Selkirkii there are two points which I (amnot make agree with the plant as I have seen it. Ife describes its general aspect as very similar to that of Viole hlanda, and grives July ans its time of flowering. The plant flowers with us early in Say-l have neell it in flower in April-and is a very small plant with pale blue flowerk, with a very long spur. Mr. Goldie ands this note to his deseription: "I showed this plant to Mr. Pursh, at . Iontrent, and he informen me that it was what he ealled Violus Selkirlio, and hence I have thought is right to adopt his natue." I have never found this plant in flower later thall May.

A new Drasern (D. Linearis) was diseovered by Mr. (rollie on the shores of Lake Simcoe, and a small primmse (Enother, Canadensis), which is not now found in the manuals ; Stellarin longipes, Ranun rulus rhomboideus and Corydalis Commlensis (prerhapes the r.glaura of Pursh) were also discoveres by him.

He appears to have mide a mistake in Mabenariu orliculatu, a latrge form of which he takes for a new speeies-II. macrophylla. Ile siys: "Of" all the orchideous plants I have seen in America, this is withont a question the langest and most striking (Orchis of Pur.wh and Nuttall), having like it two plane orbieular approaehing to elliptieal leaves, . . which in this plant are fomr times ats large as those of H. orbiculita, metsuring six to eight inches in length." IIe also deseribes the flower ans white. All who have met with this remakable plant, with the many 
rolletien and shapes of its leaves, will landly blane Goldie for his onistake, if inistake it was. Latst sunner I found in the rich woodlands of llie Uprer Restigonche n plant strikingly liko the plant deseribed by liollic, und which ought, perhaps, to be resarded as a variety of $I I$. "ulvinglutu. It was growing in tropical lixuriance, with leaves roundishoxul, from seven to eight inches in length, and it spike of white flowers fully six inches long.

The Osmmule alitta of fioldie, found on the island of Montreal and along the ottawa river, has fow specitie diflerences to distinguish it from O. Cinnumomea, hat these are well matkel, anul Slucoun and Burgess have placel it in their monograph on the ferus of Canala as a ruriety of (). cinnamomed.

Aspridium Goldianum is thus describet: "From one and a linif to two feet in height. Allied to Aspidinm cristatum more than to any other species in the grenns; but abunlantly distingnishuble lig the greater breath of the frond, which gives quite 11 diflerent outline. and by the torm of the pinna, which are never brouler at the base, but are, on tho routrary, narrower than severnl of the segments just aljove them. These segments, too, are longer and narrower, slightly follente, and those of the lowermost pinnse atre never lobed. but simply sermated at the margin. The serratures are likewise terminated by unore decided, though short spin. uls: The fructifinations are central, near the millib, and this circumstunce presents the species from bearing, as it would otherwise lo, no inconsiderable attinity to A. muryinale.

"Specimens of this plamt, eultivated in tho Botalucal carden at Filasgow, tron: roots which I hrought from Canada, retain all the charactors which I have above described." 



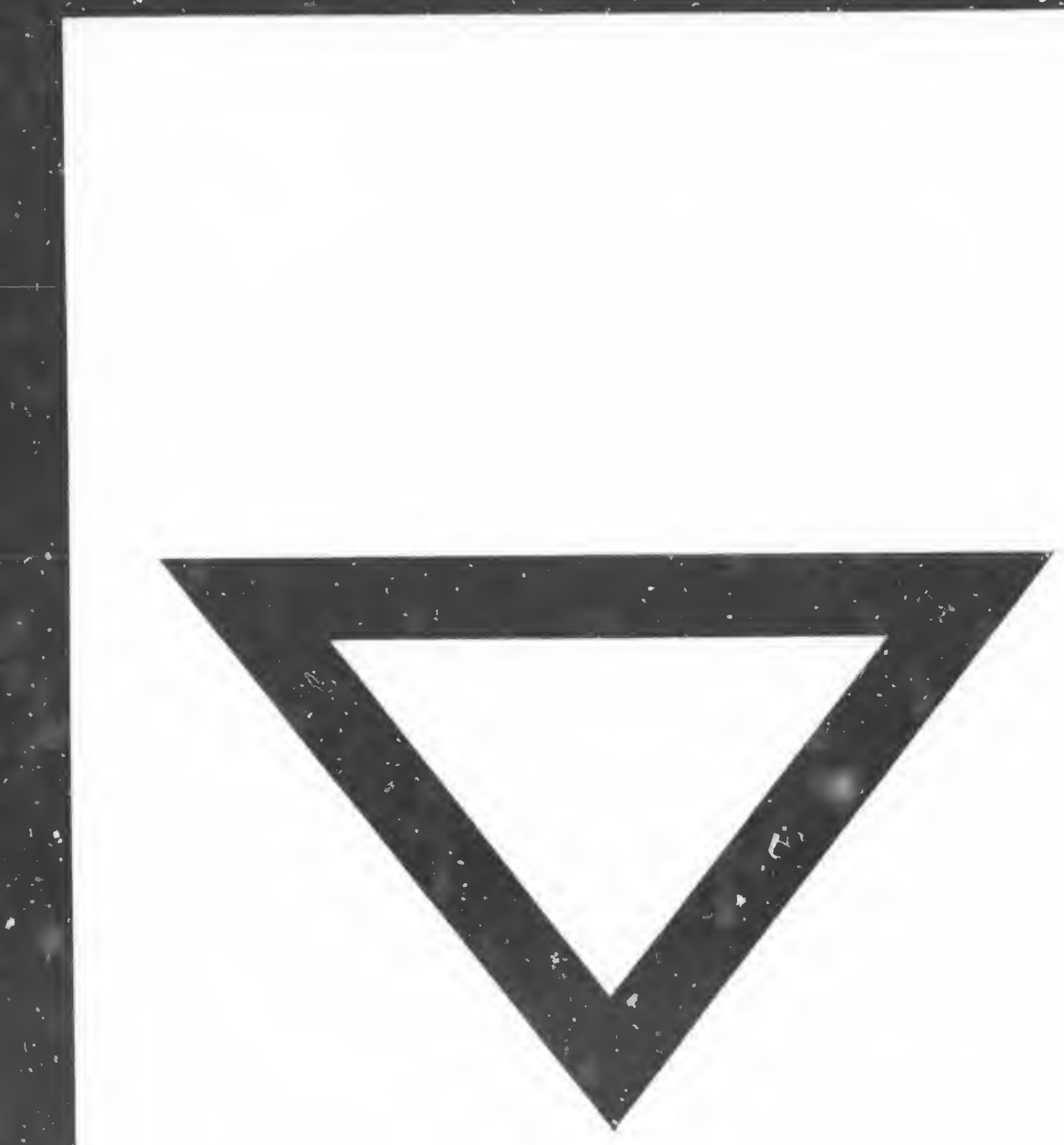

